\title{
Moral harassment of public schools teachers
}

\author{
Izabel Carolina Martins Campos ${ }^{\mathrm{ab} *}$, Alessandra da Cruz Serafim ${ }^{\mathrm{b}}$, Kamilla Valler Custódio ${ }^{\mathrm{b}}$, \\ Lizandra da Silva ${ }^{\mathrm{a}}$ and Roberto Moraes Cruz ${ }^{\mathrm{a}}$ \\ ${ }^{a}$ Federal University of Santa Catarina - UFSC, SC, Brazil \\ ${ }^{\mathrm{b}}$ State Secretary of Administration's Office, SC, Brazil
}

\begin{abstract}
Programs geared towards the occupational health of public workers, that include the prevention of moral harassment, have been created in Santa Catarina. Any institution identified for its poor records in regards to moral harassment will end up having its image tainted before society at large. This is due to its use of arbitrary and embarrassing means for accomplishing everyday tasks. This article aims to consider Workplace Psychological Harassment (WPH), its risks and implications for the health of public workers. The methodology chosen was a teacher's case study, which consisted of document research, interviews, anamnesis and observation, all in order to relate both theory and practice. The results indicate that WPH is a complex phenomenon, which can be studied in a variety of ways. WPH risks the biopsychosocial health of the worker, causing the deterioration in social-professional relations, illness, and incapacity, as well as higher costs and certain degradation in production. It is difficult to prove incidents and their impact. Nevertheless, this research concluded that WPH has harmful consequences for the physical and mental health of workers, and is in the ergonomic field, since part of this profession's role is to seek understanding of work in order to reorganize it.
\end{abstract}

Keywords: moral harassment, illness, teaching, public employee

\section{Introduction}

The goal of this article is to contextualize and reflect on the concepts of Workplace Psychological Harassment (WPH) by way of a case study from a real situation, which affected a teacher working in the public school system for the State of Santa Catarina. This case study illustrates the WPH phenomenon through the experiences of a person who faced this mistreatment and its physical and psychological implications as well as problems related to interpersonal relationships, social life, economy and professional career.

Moral harassment is referred to in international literature as mobbing, bulliyng, acoso, and harassment, among other terminology. Leymann, a German researcher who lived in Sweden, started studying this phenomenon in the 80 's. He described severe forms of moral harassment in organizations. For this author, mobbing consists on frequent and repetitive hostile actions in the workplace, which are systematically directed at one or more people. According to him, mobbing can originate from a very trivial conflict, but may end up evolving into a process of serious psychosocial stress. This phenomenon consists of a type of aggression or terrorism, of a psychosocial and/or psychological nature that takes place in the context of work [14].

In Brazil, the precursors of the WPH or psychological harassment where $[2,8,20,11]$, who were influenced by de $[12,15,22]$. The WPH is characterized by violating a person's dignity and by repeated experiences of humiliation and embarrassment, which can cause trauma and trigger social isolation, anxiety, as well as the development of drug and alcohol addiction. It may also provoke depression, panic attacks, anguish and sadness.

An ergonomist role is directed towards the importance of human activity analysis in work situations [5]. This activity brings together phenomena of physiological, cognitive, psychic and social order that the professional puts in action in order to carry out his task [9]. Therefore, an ergonomist's approach should allow him/her to detect the risks related to moral harassment in such a way that would help to prevent damage [5].

\footnotetext{
${ }^{*}$ Corresponding author. Campus Universitário - Trindade - Florianópolis - SC - Brazil. Cx Postal: 476. CEP 88040900. Tel: +5548 37217104, Fax: +55 48 37217032. E-mail: izacarol@gmail.com
} 
A gap was identified in the study of moral harassment from the viewpoint of ergonomics. Work deterioration leads to incapacity and constraint [9]. Ergonomists need to assess not only the visible risks, but also psychological violence and the subjective components of one's work.

It is worth noting the absence of a federal Brazilian law dealing with this issue, making punishment of an alleged aggressor possible only when an individual judge determines such an action to be prudent. Contrary to what occurs with sexual harassment, there is no law in Brazil that specifically prohibits moral harassment. Doctrine, precedents and case law from labor courts aim to curb the harassers and by these means alone can these acts of violence, whether intentional or not, be contained.

At the executive state level in Santa Catarina, the government, through the Administrative Secretary of State, the Board of Health and the Agency for Occupational Health, created legal tools to insure the health and safety of workers. These tools put into place guidelines for the management system of the occupational health of workers and also advocated steps that would improve the organization, work relationships and working environment of the worker. Law $\mathrm{n}^{\circ}$ 14.609, from the 7th of January, 2009 [15], instituted the State Program for the Occupational Health of Public Servants and the Decree $\mathrm{n}^{\circ} 2.709$, from the 27th of October, 2009 [6] established the Occupational Health Manual.

In the Occupational Health Manual, Chapter IX, the Moral Harassment Prevention Program in Santa Catarina is described [17]. It aims to prohibit and prevent this phenomenon in the public sector. According to this text, article $\mathrm{n}^{\mathrm{o}} 1$ establishes that:

Moral Harassment from superiors or colleagues, within the state's public system, whether direct or indirect, must be curbed by avoiding situations that submit workers to repetitive procedures that violate their dignity or that, in any way, subject them to humiliating or degrading working conditions.

This rule clearly states what may be considered moral harassment. It also explicates attitudes that characterize this type of violence in the workplace; looks at how moral harassment should be measured; provides penalties to be applied to the aggressor in accordance with the worker's rights, after the conclusion of an administrative process; and finally, it regulates the actions to be performed by agencies and entities of the state government.

This article does not intend to exhaust the subject of all possible moral harassment situations. Instead, the goal of this article is to contextualize the litera- ture in some biopsychosocial aspects, by means of a state teacher's case study.

\section{Method}

For this article we opted on a case study whose accounts belong to a public school teacher for the State of Santa Catarina. Even though the case study methodology is not conclusive for the formulation of new theories, the multiprofessional approach, proposed by the authors of this article, intends to contribute to the studies of moral harassment. Understanding the same phenomenon from different professional viewpoints optimizes the description and analysis of the facts, demonstrating the complexity in social relationships within the workplace.

The case study permits the illustration and the unveiling of qualitative relations about the moral harassment phenomenon. The intensive outline of a case allows for the discovery of social relationships that would not have been found in any other way. This is due to analysis and inferences that are taken from evidence of similar situations with the goal of dissecting the social historical context [23]. The assessment of the collected data was proceeded mainly by analogies, comparing theories and other cases.

Through health records and other documents research, as well as the State Occupational Accident Communication process, a case study on the moral harassment of a teacher was created. This was then contextualized in an extensive review of literature. Health records are official, state-issued documents that register all of the health/illness history of a state employee who has generated any type of compensation or benefit, such as permission for leave on reason of personal or family health problems, or even the removal, rehabilitation or retirement, etc. of said employee. The records include expert medical, psychological and social assistance evaluations. The State Occupational Accident Communication process seeks to recognize the link between physical or mental damage and the tasks carried out by the public servant, the evaluation being performed by a multiprofessional group, in the field of occupational health.

The technical resources and instruments that were used came from reports issued by health professionals at the Public Servants Board of Health (interviews with the employee and other witnesses, observations, anamnesis, psychological tests and institutional contact), with the goal of helping in the search for information consonant to the literature. 


\section{Documented research of workplace psychological harassment}

Workplace Psychological Harassment (WPH) is characterized by psychological violence that submits the worker to certain constraints. A victim of WPH suffers in ways that may ultimately have serious consequences, such as depression; anxiety, fear or even panic when going to work; stress and, in some grave cases, could even lead to suicidal thoughts or acts. Therefore, WPH is prolonged and repetitive exposure to vexatious and humiliating situations in the workplace that are characterized by inhuman and authoritarian hierarchical relationships which may embarrass the victim in front of his/her colleagues or even isolate them from the group [2].

$\mathrm{WPH}$, or moral harassment is a risk factor to a worker's health which may provoke devastating effects and is characterized by aggressive gestures, competition, humiliation, conflict, power disputes, physical threats, serious reoccurring vexatious conduct, embarrassment, ridicule, isolation, psychological torture and envy in the workplace [15].

It consists of abusive conduct that attacks the dignity and the psychological or physical integrity of a person and puts their job at risk or degrades the work environment [12]. It also exists when the activity is spoiled by suffering, which can result in disability, illness or other constraints [9].

It constitutes a potential "psychosocial risk" that can be understood as job characteristics that act as stressors, causing major labor demands, intertwined with insufficient resources for the worker to face those demands [10].

The psychosocial risk factors are those conditions that are present in a work situation that are directly related to the organization, work load and the performance of certain tasks that have the capacity to affect the physical, psychological or social health of the worker and the work completion [17]. According to Assunção [1], dissatisfaction and negative work perception are also psychosocial risk factors.

The personal and material damages are revealed as the main judicial consequences of moral harassment in the workplace, namely, when repeated abusive conduct that is psychological in nature and produces damages to an individual's dignity for the purposes of exclusion. The psychological damage reveals itself as such illnesses: stress, anxiety, insomnia, headaches, gastritis, depression, post-traumatic stress disorder and panic syndrome, among others. The compensation of the damage caused by WPH for the worker must happen by through the judicial system, where the proof of events and damages may be observed [3].

In addition to the legal realm, state workers can also appeal administratively, request the opening of an inquiry process and or administrative process, guaranteed by the Moral Harassment Prevention Program in Santa Catarina [17]. Any state worker that is a victim of moral harassment has the possibility of opening a State Occupational Accident Communication process. An occupational accident is understood to be anything that causes "mental or physical harm to the worker and is related, either directly or indirectly, to the completion of functions, activities or duties of the position that he/she occupies", according to Decree $\mathrm{n}^{\circ}$ 1456, December 23rd, 1996 [16]. In accordance with this legal apparatus, illnesses brought on by work, whether or not they have specific legislation, so long as they present a correlation to the activities performed, will still be considered occupational accidents. Moreover, following the communication of such incidents, state workers are assured payment or reimbursement of arising costs.

As a result of WPH the victim may present the following disorders: Post-Traumatic Stress Disorder (PTSD), General Anxiety, Adjustment Disorder (AD) and depression, among others. These disorders consist of psychiatric conditions resulting from an individual's response to stressors as well as some changes in the social life of the affected individual. Signs and symptoms may include: affliction, incapacity to work normally, difficulty in performing daily tasks, among others. Depression and general anxiety disorders are pathologies that are commonly diagnosed, however, there are other disorders that frequently go undiagnosed, such as Post-Traumatic Stress Disorder (PTSD) and Adjustment Disorder (AD) [4].

According to Freire [7] a victim of moral harassment may present psychopathic, psychosomatic and behavioral disorders. The psychopathological disorders are manifested with symptoms of anxiety, depression, anguish, mood swings, irritability, lack of self esteem, stress and irritation. The psychosomatic disorders are revealed through physical symptoms whose origin is psychological. Some examples are: asthma attacks, stomach ulcers, migraines, labyrinthitis, torticollis or wryneck, hair loss, muscle and joint pain, stress, high blood pressure and insomnia. Behavioral disorders are evident through aggressive reactions, eating disorders, increased smoking, drinking and drug use, sexual dysfunction, social isolation and crying. 
Thus, moral harassment can cause: moral and psychological damages; competence crises; contractual losses; drop off in productivity; higher costs for the victim, the organization, social security and society as a whole. It may also generate an overall incapacity to work.

Situations of WPH in the public sector may occur in a visible and memorable fashion. There are some peculiar characteristics that can lead to the victimization of certain people: when a boss does not identify with a worker and yet cannot fire him/her, he/she may decide to humiliate or embarrass him/her. Notably, in the public sector, superiors are generally nominated for their position because of their influence or personal friendships and not because of their technical qualifications or preparation to perform their particular managerial function. The upper hierarchy of public administrative offices is anchored on the relationships, which guarantee these types of recommendations, which can become arbitrary, seeking to offset their limitations and, on the other hand, considering themselves untouchable [12].

\section{Results and discussion}

\subsection{Workplace psychological harassment within the context of Maria's case}

Maria - ficticious name - is fifty years old, married with three children - two adults. She has notoriety for being knowledgeable in her field of study and came into the public arena four and half years before, working at a state-sponsored school as a teacher with a forty-hour work week. Before being hired by the state school system she had worked for fifteen years in a city government position in the medical field and then six years as a teacher at a private school in another state.

According to Maria, from the beginning her immediate boss did not create an adequate work environment that would have allowed her to do her job. Instead, the boss would foster poor relations between the other teachers, was rude to women and yelled constantly. He favored some of the teachers and diverted public funds in a systematic and explicit way. He used public resources in a way that was not consistent with an educational context. Unable to stand this environment some of the teachers requested and later were able to get transferred to other schools.

According to Maria, her boss insisted that she performed administrative tasks that were not part of her job description in order to make up for deficiencies of his own administration. Maria began suffering vilification at work, was spied on by the administration staff as well as security guards during her classes and she was also attacked and called incompetent and undignified in her activities. In addition, she was subjected to abusive conduct, students who became close to her also suffered discrimination, threats and opportunity restrictions from the institution's administration.

Given the worsening of the psychological violence to which Maria was being subjected after two years of work, she applied for a transfer to another school. This transfer request was not granted by her superiors.

It is worth noting that the abuses continued beyond the work environment and into Maria's family life. During her initial work absence the institution's coordination commented to Maria's colleagues that her illness, which prompted her absence, was caused by problems with her adolescent children whom he suggested were "drug addicts". This fact was corroborated by the oral testimony of witnesses who were interviewed during the State Occupational Accident Communication process investigation.

During her first visit, the doctor recognized Maria as the woman that he had given an entrance exam to two and a half years earlier. Due to her clinical situation he referred her to a social worker. After evaluation, this team of health experts recommended her to request a removal from the school due to medical reasons. The request of this psychiatrist was that Maria tried to perform the same duties at another school, in a different geographical location.

Another school had expressed interest in receiving Maria, registering in an official letter that she is a highly qualified and productive professional and would be well-received due to her charisma and technical knowledge. However, the administration of her current school did not grant the transfer.

Gradually, Maria became ill, and after two and a half years she left her position to seek medical attention. At the time she was presenting the following symptoms: insomnia, lack of appetite, anguish, heightened level of anxiety and hopelessness, lack of air, nausea, palpitations, constant crying, sadness, suicidal thoughts, fear, insecurity, lack of motivation, low self esteem, anhedonia (inability to feel pleasure), isolation, lack of concentration and memory loss. At the height of her suffering, she would not get out of bed, could not handle bright light, would not take a shower for fifteen days at a time, stopped eating, did not look at herself in the mirror, lost six kilos - more than ten percent of her overall weight - could not 
sleep, had no sense of time either past or future and was always nervous.

It is important to reiterate that the signs and symptoms that Maria had, due to the violence that she was submitted to, are compatible with the research [21, $12,2,4]$.

An interviewed witness affirms the existence of a political dispute between two groups in the school and the group that is currently in power holds back those who do not share their ideas, making access to needed resources and the fulfillment of their job difficult. These accounts match the ones Maria shared, concerning several offences carried out by her superiors, such as: misuse of public funds; verbal attacks; different forms of discrimination; photographic records of Maria doing her normal daily activities while she was on medical leave (taken with the intention of proving that Maria was, in fact, healthy); forcing her to do things which were not part of her job description; among others. These testimonies also revealed that Maria "was a rational person, concentrated, balanced, happy, positive; but now she is always sad, anxious, complaining, afraid of everything and constantly swearing".

The review process for granting medical leave is started by delivering a specific document to the $\mathrm{Hu}$ man Resources Department. This must be done before the public servant undergoes an expert evaluation. Despite Maria's and the HR's request to send this document, it was refused twice which made the extension of her medical leave difficult. Thus, it was left up to the HR department to use their legal authority to extend her medical leave after assessing her obvious incapacity to return to the workplace.

Maria then carried out a State Occupational Accident Communication process. In the field designated for the physician's assessment, the psychologist wrote: "Serious depression without psychotic symptoms. Severe symptoms, such as anhedonia and sadness...". The psychological evaluation of Maria's case included analysis of documents, medical records and interviews with witnesses. The evidence showed that Maria suffered psychological damage from incidents that occurred within the workplace. It furthermore revealed a link between Maria's psychopathology and her working conditions, thus characterizing her illness as a workplace accident. She was retroactively granted medical leave.

However, in spite of the power afforded to the state to grant medical leave as well as other benefits that would cover the reimbursement of treatment expenses, up until the time that this article was written, Maria's institution has refused to accept the med- ical leaves, and has denied her leave, transfer or removal. Furthermore they refuse to accept the findings of the Moral Harassment Prevention Program and to reimburse her expenses, which she sustained due to conditions within her workplace environment.

The institution does not seem to realize that Maria has been damaged psychologically in a way that would justify medical leave extensions, much less her removal from her current work environment. The institution claims she is using said health problems and psychological conflicts at work in order to attain her transfer. Administrative documents related to the situation state that Maria's situation is very mild. Their evidence of this is the simple fact that she has been seen in supermarkets, airports and beauty salons.

This situation of harassment and the fact that she had been monitored and photographed caused her to move her family to another house. This intimidation generated a situation within her family of insecurity and fragility, worsening her depressive profile as well as her anxiety and feelings of hopelessness.

The institution where Maria works has undertaken efforts to see her fired. They have started administrative and judicial processes, alleging that she missed days over the official holiday periods. They used these proceedings to deprive her of a month's salary and they also discounted following missed days.

In recorded cases that figure as psychological harassment, the objective of the instigator(s) is to shake the organic or psychological state of the target victim so that they become willing to quit their job, abandon their post, or give up their rights or even reduce themselves before their peers, from the standpoint of social or individual morality [15]. This is exactly the same situation that we see in Maria's case. The diagnosis of her state of health and the context of her work relations, according to health professionals and supported by state legislation constitutes an important component. However, the institution's response to this diagnosis could be an even more important factor since it denies her condition of illness, along with her benefits as a public worker, such as medical leave and reimbursement of medical expenses.

Thus, Maria continued on medical leave in order to obtain medical treatment aimed at her recovery, staying away from the hostile environment and work relations. Furthermore, together with her lawyer, she sought to defend herself from the suits being filed against her and also filed legal suits seeking compensation for moral damages after the fact.

The results of the analysis of this case corroborate with the definition criteria for moral harassment - the procedural nature; frequency and duration; the identi- 
fication of a specific target; unbalanced power and intentionality [19]. There is a procedural nature, in the sense that the humiliations and psychological violence that Maria was subjected to were of an evolutionary sort, which progressively worsened. Reiteration is perceived in relation to systematization and constant repetition of abusive conduct to which Maria was exposed: hostile attitudes directed at her by her immediate boss, the denial of benefits and the opening of administrative and judicial processes against her.

The harassment has gone on for over six months, the period referred to in literature, mainly because, in spite of being on medical leave, Maria is currently defending herself against administrative and judicial charges. This is still certainly a source of great anguish and torture. As far as specific targets are concerned, one only needs to take note of the fact that these abuses were directed at a specific person: Maria.

As far as the subject concerning power relations, we can clearly see the inequality in power, with an asymmetric interaction between the agitator and the victim, of a descending nature - from supervisor to subordinate. The offenses come directly from the immediate superior and from the institution as a whole, in a way that left Maria without any means to defend herself. Insofar as the intentionality is concerned, although it is complex to verify in attitudes and intentions to cause harm, we can see that hostile practices are deliberate and that they represent an intention to hurt her.

It is obvious that Maria was submitted to repetitive and embarrassing situations as well as psychological violence at work. This situation created illness and incapacity to work, while damaging several different areas of her life including her social, personal, professional and financial environments.

\section{Conclusion}

Workplace Psychological Harassment (WPH) is characterized by a series of actions or omissions in unequal power relations, with a focus on derogatory actions, in a repetitive and prolonged way, which seeks to destabilize the victim. The phenomenon brings harmful consequences to the physical and mental health of the worker. Proving the existence of WPH and the damage that it causes is a difficult task, keeping in mind that it is, normally, a subtle, insidious process and, sometimes, invisible. This has a tendency to make the situation significant only for the people involved.

Understanding the workplace in order to promote its transformation is an ergonomist's job. Considering that WPH is a new field of intervention it is indispensible to understand the worker, keeping in mind that WPH is a complex phenomenon within the workplace. An ergonomist can act within the awareness and prevention levels, taking advantage of the ergonomic tools at their disposal with the intention of applying them in intervention plans within the organizations where they work.

Facing and preventing new situations of WPH is possible when one is aware of the phenomenon, the involvement of unions, associations and workers. Professionals can also rely on new laws, campaigns and other activities in order to guarantee changes in work relations and conditions.

As far as public service in Santa Catarina, chapter IX of Decree $n^{\circ} 2709$ ensures mandatory actions related to the prevention and combating of this type of violence in the workplace [17]. The Guidelines and Procedural Manual works as an expedient means to optimize the implementation of this legal provision.

\section{References}

[1] A. Á. Assunção, Trabalhar sim, adoecer não! In: Anais do II Conferência Municipal de Saúde do Trabalhador de Piracicaba; 2005 Set 17; Piracicaba: São Paulo; 2005.

[2] M. S. Barreto, Uma jornada de humilhações, Dissertação de mestrado, Pontifícia Universidade Católica de São Paulo, 2000.

[3] R. da C. L. de G. Barros, Assédio moral: Dos Efeitos e Aspectos Probatórios do Psicoterror no Ambiente de Trabalho Empresarial. In: Anais do VII Encontro Preparatório para o Congresso Nacional; 2008; Salvador: Bahia; 2008.

[4] Cassito, M. G. et. al. Sensibilizando sobre el acoso psicológico en el trabajo: orientación para los profesionales de la salud, tomadores de decisiones, gerentes, directores de recursos humanos, comunidad jurídica, sindicatos $y$ trabajadores. (Serie protección de la Salud de los Trabajadores, 4, OMS/FISO, Genebra, Bogotá, 2004, 38 p. Retrieved on Nov 6, 2008 from http://www.who.int/occupational_health/publications/harassm ent/es/index.html

[5] F. Doppler, Trabalho e Saúde, in: Ergonomia, P. Falzon, Editora Blucher, São Paulo, 2007, pp. 47-58.

[6] ESPAÑA. Ministério de Trabajo y asuntos sociales, Instituto Nacional de Seguridad e Higiene Social em El Trabajo. NTP 476 - Norma Técnica de Prevenção; El hostigamiento psicológico en el trabajo: mobbing. Retrieved out 11, 2010 from http://www.mts.es-insth-principal-consult_cnn.htm

[7] P. A. Freire, Assédio moral: a violência no ambiente de trabalho e suas conseqüências para a saúde mental do trabalhador. Revista Trabalho, Educação e Saúde 6, 2 (2008) 367-380. 
[8] M. E. Freitas, et al, Assédio moral no trabalho, Cengage Learning, São Paulo, 2008.

[9] F. Guérin, A. Laville, F. Daniellou, J. Duraffourg, A. kerguelen. Compreender o trabalho para transformá-lo, Editora Edgard Blucher, São Paulo, 2001.

[10]L. A. M. Guimarães and A. O. Rimoli, "Mobbing" (assédio psicológico) no trabalho: uma síndrome psicossocial multidimensional", Revista Psicologia: Teoria e Pesquisa 22, 2 (2006) 183-192.

[11] R. Heloani, Assédio Moral: um ensaio sobre a expropriação da dignidade no trabalho. RAE-eletrônica, 3, 1 (2004) 1-8.

[12]M. F. Hirigoyen, Assédio moral: a violência perversa no cotidiano, $5^{\circ}$. ed, Bertrand Brasil, Rio de Janeiro, 2002.

[13]B. M. Jiménez, et al, El Acoso Psicológico. II plan director en prevención de riesgos laborales de la comunidad de Madrid. Secretaría de Salud Laboral y Medio Ambiente de UGTMadrid. Secretaría de Comunicación e Imagen de UGTMadrid, Madrid, (2004-2007).

[14]H. Leymann, The content and development of mobbing at work, European Jornal of Work and Organizational Psychology 5, 2 (1996) 165-181.

[15]I. Pyñuel Y Zaballa, Mobbing: como sobreviver ao assédio psicológico no trabalho, Edições Loyola, São Paulo, 2003.

[16]Santa Catarina. Decreto n ${ }^{\circ}$ 1456, de 23 de dezembro de 1996. Dispõe sobre a assistência aos servidores públicos estaduais, em decorrência de acidentes em serviço e doença profissional, nos órgãos da administração direta, autarquias e fundações do poder Executivo. Diário Oficial do Estado de Santa Catarina.
[17] Santa Catarina. Decreto $n^{\circ} 2.709$, de 27 de outubro de 2009 , no âmbito da administração pública estadual direta e indireta. Dispõe sobre Manual de Saúde Ocupacional do Servidor Público. Diário oficial do Estado de Santa Catarina.

[18] Santa Catarina. Lei $n^{0} 14.609$, de 7 de janeiro de 2009. Institui o Programa Estadual de Saúde Ocupacional do Servidor Público de Santa Catarina.

[19] M. A. Schatzmam, Violência moral sob a luz de categorias de Bourdieu, Verón e do círculo de Bakhtin. Assédio moral interpessoal e organizacional: um esforço interdisciplinar, LTr, São Paulo, 2009.

[20]L. Soboll, Violência psicológica e assédio moral no trabalho bancário, Tese de doutorado, Universidade de São Paulo, 2007.

[21]D, Zapf, Organizational, work group related and personal causes of mobbing/bullying at work, International Journal of Manpower 20 (1999) 70-85.

[22]D. Zapf et al. Organizational, work group related and personal causes of mobbing; bullying at work, International Journal of Manpower 20, 1/2 (1999) 70 - 85. Retrieved on set 16, 2011 from

http://www.emeraldinsight.com/10.1108/01437729910268669

[23] R. Yin, Estudo de caso: planejamento e métodos, Bookman, Porto Alegre, 2001 